\title{
IMPROVEMENT OF THE CASTING OF SPECIAL STEEL WITH A WIDE SOLID-LIQUID INTERFACE
}

\author{
IZBOLJŠANJE ULIVANJA POSEBNEGA JEKLA S ŠIROKIM \\ INTERVALOM TRDNO-TEKOČE
}

\author{
Tomas Mauder, Josef Stetina \\ Brno University of Technology, Faculty of Mechanical Engineering, Technicka 2, 61669 Brno, Czech Republic \\ mauder@fme.vutbr.cz, stetina@fme.vutbr.cz
}

Prejem rokopisa - received: 2014-07-29; sprejem za objavo - accepted for publication: 2015-03-03

doi: $10.17222 /$ mit.2014.122

\begin{abstract}
In the last few years, steelmakers have been facing a significant decrease in the steel demand caused by the global economic crisis. Positive economic results have mostly been reached in the steel factories that have focused on special steel production with higher product capabilities, such as higher strength grades, steel design for acidic environments, steel for the offshore technology, etc. These steels must keep the mechanical properties, such as the resistance to rapture, compression strength, stress-strain properties, etc., within strict limits. The numerical calculations and optimization of casting parameters were provided. The results show the recommended casting parameters and differences between the examined steel and classic low-carbon steels.

Keywords: continuous casting, experimental measurement, numerical simulation, optimization
\end{abstract}

Proizvajalci jekel se zadnja leta spopadajo z zmanjševanjem povpraševanja po jeklu, kar je posledica globalne ekonomske krize. Pozitivne ekonomske rezultate so dosegle železarne, ki so se osredinile na proizvodnjo posebnih jekel in z večjimi proizvodnimi zmogljivostmi, kot so visokotrdnostna jekla, jekla za delo v kislem okolju, jekla za naftne ploščadi itd. Ta jekla morajo v ozkih intervalih obdržati svoje mehanske lastnosti, kot so pretrg, tlačna trdnost, raztezek pri nategu itd. Izvršeni so bili izračuni in optimizacija postopka ulivanja. Rezultati kažejo predlagane parametre litja in razlike med preiskovanim jeklom in navadnim maloogljičnim jeklom.

Ključne besede: kontinuirano litje, eksperimentalne meritve, numerična simulacija, optimizacija

\section{INTRODUCTION}

Continuous casting (CC) of steel, as an industrialized method of solidification processing, has a relatively short history of only about 60 years. In fact, the $\mathrm{CC}$ ratio in the world of steel industry now reaches more than $95 \%$ of crude-steel output (Figure 1). ${ }^{1-3}$ Through the years, the product quality, production efficiency, operating safety and casting of special steels and alloys have increased. Today, nearly all steel grades can be produced and productivity goals exceed by far those envisaged in the 1960s/1970s; the limits of casting-section sizes have been increased to support new steel-grade developments like thick high-strength steel plates or to realize new process routes like the direct link between the casting and rolling steps. ${ }^{4}$

In the early 1990s, continuous casting was an established and already matured technology. The production was focused on cost reductions through higher casting speeds, a better utilization of energy, the optimization of equipment performance and a reduction of the maintenance expenses using the equipment with a longer lifetime. The key factor, which made continuous casting the "main-stream technology", was the continuous innovation. From the metallurgical point of view, the stateof-the-art continuous casters have the features that enable strand treatment through special cooling and soft-reduction technologies. ${ }^{5}$ Sophisticated process models allow an online process simulation and closed-loop control to further optimize the product quality and productivity goals.

Today, steelmakers in the European Union are facing a significantly decreasing steel demand caused by the global economic crisis. Figure 1 shows the crude-steel production progress in the EU between 2005 and 2012

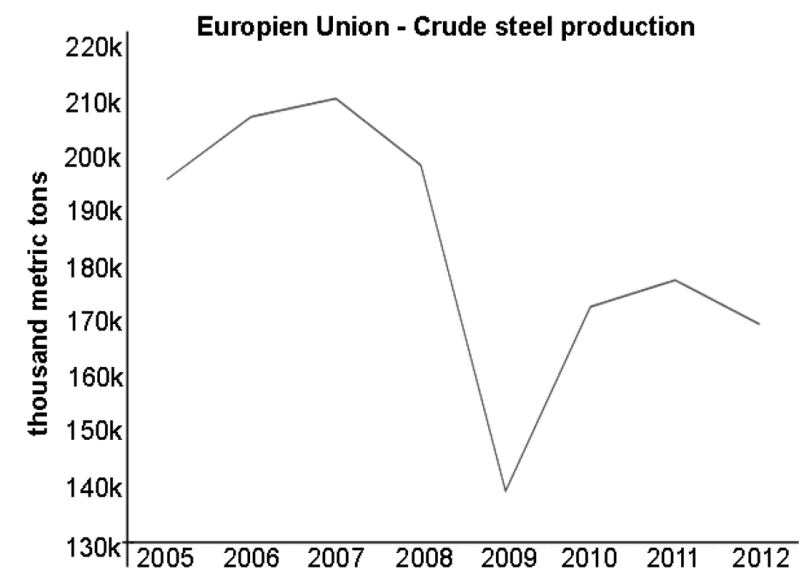

Figure 1: Crude-steel production in $\mathrm{EU}^{2}$

Slika 1: Proizvodnja surovega jekla v EU² 
promulgated by The World Steel Association. ${ }^{2}$ The economic crisis in 2008 caused a deep slump in the steel production in the EU. Positive economic results were mostly reached by the steel factories that focused on special steel production with higher product capabilities, such as higher-strength grades, steel plates for barrel boilers, steel design for acidic environments and steel for the offshore technology. The production of special steel is the only prospective for the EU to keep the competitiveness with the Asian market.

Steel grades for acidic environments and for the offshore technology must keep the mechanical properties, such as the resistance to rapture, compression strength, stress-strain properties and so on, within strict limits. A breakdown situation caused by a low quality of steel could have a catastrophic effect on the material and human losses. The defects of the steel for acidic environments have been known more than 50 years. Despite that, the world oil, gas and engineering companies still make huge efforts to improve the operations in acidic environments and to avoid critical situations. The mechanical properties for these grades of steel are specified by the European Standard EN 10020. Their production, unlike the classic low-carbon steel grades, requires a special treatment like the soft reduction, electromagnetic stirring, different cooling conditions, etc., to avoid crack defects.

The casting of special steel (C0.18, Ni0.04, V0.004, N0.003 w/\%) was performed by the steelmaker Vitkovice Steel, a. s. A macroscopic examination (the Baumann method) shows many defects in the final quality of the steel, such as high porosity, centerline segregation and cracks.

This paper deals with the results of a numerical simulation of the temperature field and optimization of a casting process by analyzing the casting parameters and their influences on the quality of the steel. ${ }^{6}$

\section{DATA FROM THE MACROGRAPHY}

The testing set contains twenty-five samples from four heats (casting sequences). With a macroscopic test,

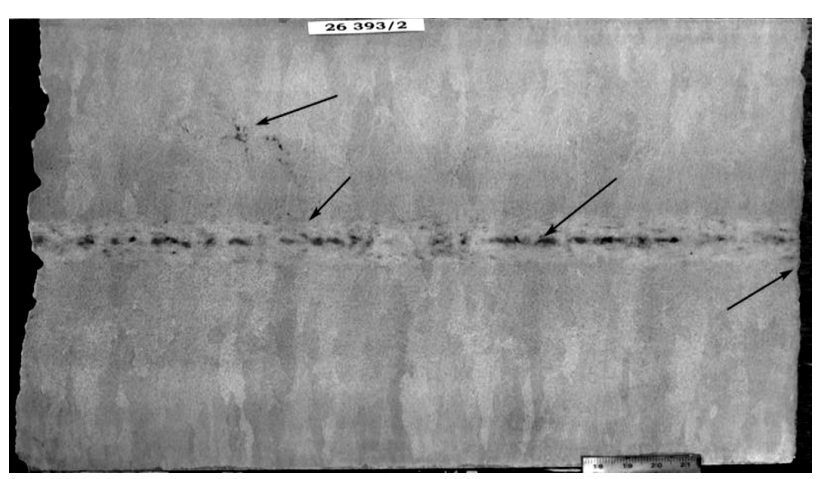

Figure 2: Steel sample from heat 26393

Slika 2: Vzorec jekla iz taline 26393 we evaluated the cracks in the transverse and longitudinal directions, the centerline segregation according to SMS DEMAG, the segregation index, the discontinuity and the lack of homogeneity.

The chemical composition of the steel is in Table $\mathbf{1}$ and the macrography results are shown in Table $\mathbf{2}$ and Figures 2 to 5 .

Table 1: Chemical composition of the examined steel in mass fractions, $w / \%$

Tabela 1: Kemijska sestava preiskovanega jekla v masnih deležih, $w / \%$

\begin{tabular}{|c|c|c|c|c|}
\hline $\mathrm{C}$ & $\mathrm{Si}$ & $\mathrm{Mn}$ & $\mathrm{P}$ & $\mathrm{Cr}$ \\
\hline 0.18 & 0.38 & 1.49 & 0.021 & 0.07 \\
\hline $\mathrm{S}$ & $\mathrm{Ni}$ & $\mathrm{Mo}$ & $\mathrm{Cu}$ & $\mathrm{Al}$ \\
\hline 0.004 & 0.05 & 0.017 & 0.028 & 0.029 \\
\hline $\mathrm{Nb}$ & $\mathrm{Ti}$ & $\mathrm{V}$ & $\mathrm{Ca}$ & \\
\hline 0.001 & 0.003 & 0.004 & 0.003 & \\
\hline
\end{tabular}

Table 2: Macrostructure results

Tabela 2: Ocena makrostrukture

\begin{tabular}{|c|c|c|c|c|c|c|c|}
\hline \multirow[b]{2}{*}{ 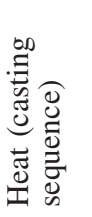 } & \multicolumn{7}{|c|}{ Macrostructure } \\
\hline & 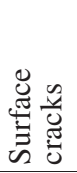 & 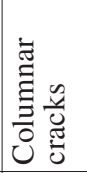 & 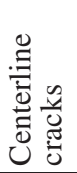 & 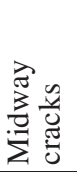 & 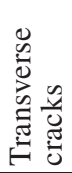 & 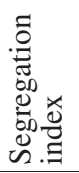 & $\sum_{\sim}^{\infty} \sum_{\infty}^{\infty}$ \\
\hline 26393 & 6 & 106 & 23 & 106 & 5 & 3 & 2 \\
\hline 26394 & 5 & 107 & 23 & 107 & 5 & 2 & 2 \\
\hline 26395 & 6 & 103 & 23 & 105 & 5 & $1-2$ & 2 \\
\hline 26396 & 5 & 108 & 22 & 107 & 5 & $2-3$ & 3 \\
\hline \multicolumn{3}{|c|}{ occurrence of defects } & \multicolumn{5}{|c|}{$\begin{array}{c}\text { Centerline segregation, cracks, local } \\
\text { discontinuity }\end{array}$} \\
\hline
\end{tabular}

From the results, it is obvious that the quality of the steel is not sufficient and has to be improved.

\section{NUMERICAL SIMULATIONS}

The simulation of the continuous-casting process is based on a transient numerical model of the temperature field. This model was specially modified to simulate the real casting machine operated in Vitkovice Steel, a.s. The

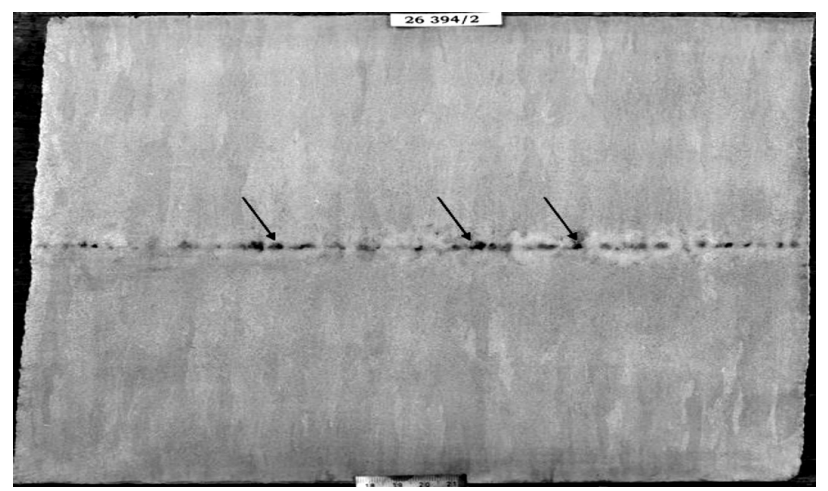

Figure 3: Steel sample from heat 26394

Slika 3: Vzorec jekla iz taline 26394 


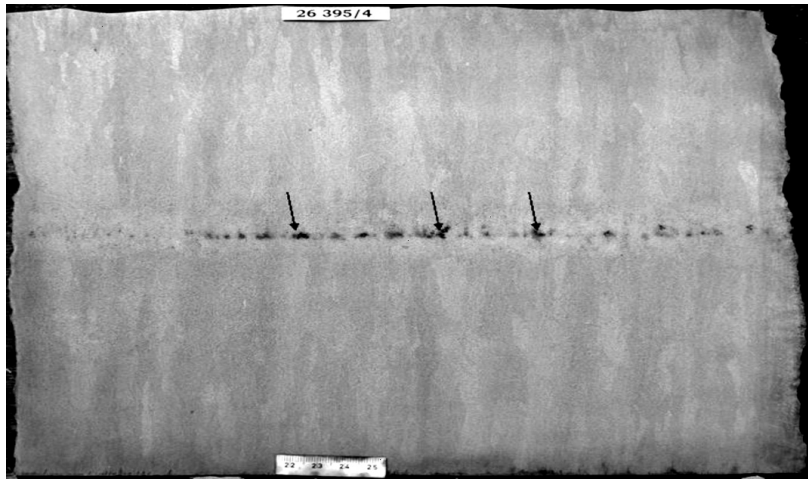

Figure 4: Steel sample from heat 26395

Slika 4: Vzorec jekla iz taline 26395

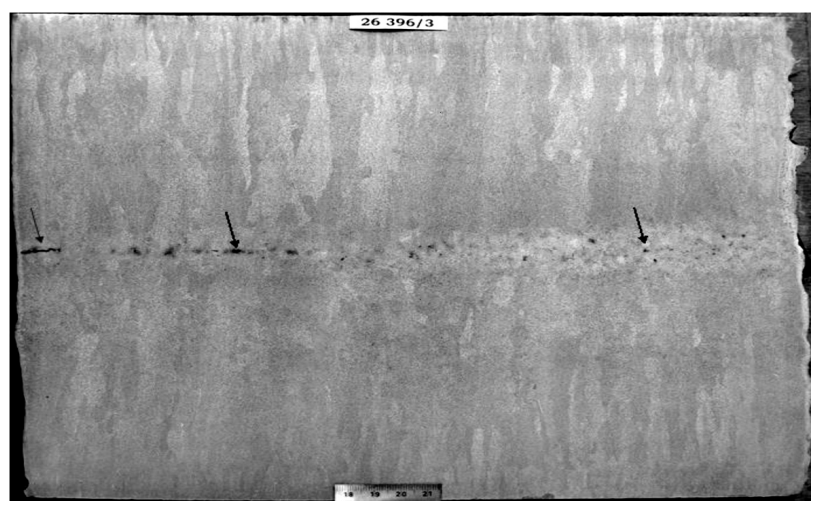

Figure 5: Steel sample from heat 26396

Slika 5: Vzorec jekla iz taline 26396

model represents a unique combination of numerical modeling and a large number of experimental measurements. Its results are validated with long-time measurements made during the real casting process. A detailed description of the numerical model can be found in ${ }^{7}$.

Thermophysical properties are calculated by the IDS solidification package. The results for the examined steel are in Figure 6.

The casting parameters, such as the casting speed, the pouring temperature, the heat removal from the mold, the cooling intensity in the secondary cooling zone, etc., for the numerical simulation were taken from the real

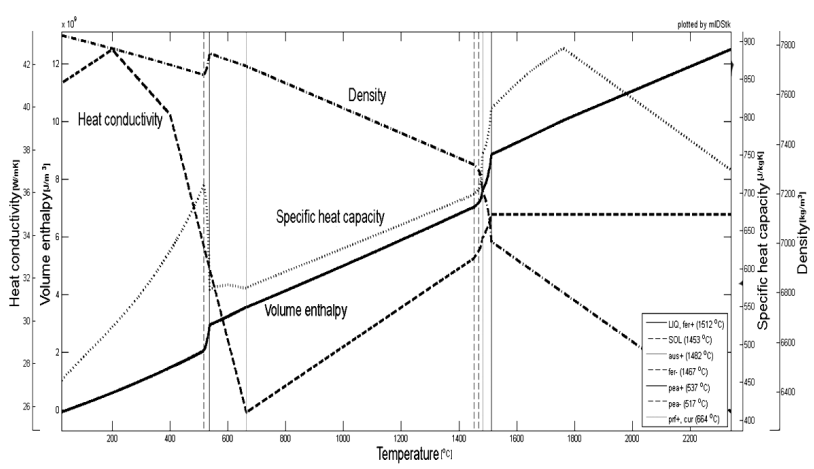

Figure 6: Thermophysical properties of the examined steel Slika 6: Fizikalno-termične lastnosti preiskovanega jekla

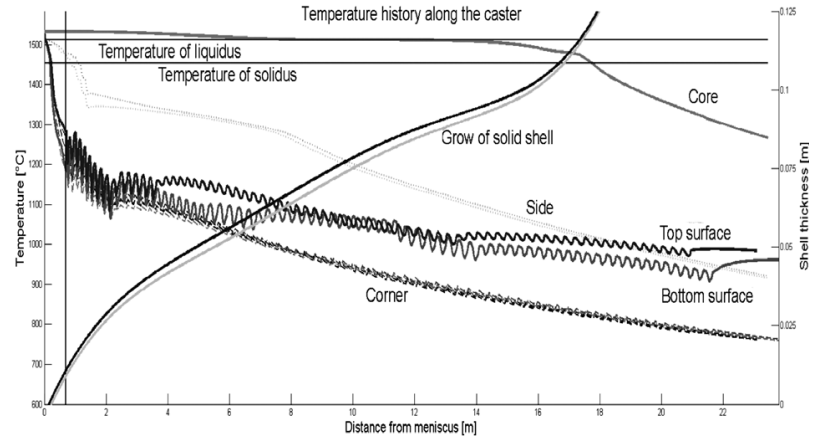

Figure 7: Temperature distribution before optimization Slika 7: Porazdelitev temperature pred optimizacijo

measurement data for heats 26 393-26 396. The results from the simulation of heat 26393 are in Figures 7 and 8.

The numerical simulation reveals that the exanimated steel is characterized by a long mushy zone in comparison with the classic low-carbon steels. The metallurgical length reaches $20.08 \mathrm{~m}$ and the mushy zone is almost $10 \mathrm{~m}$ long. For the classic low-carbon steels, the mushy zone is proximately $4-6 \mathrm{~m}$ long. The inner quality of steel is also influenced by the position of the metallurgical length. The steel should be fully solidified in close distance to the caster unbending point. The caster operating in Vitkovice Steel, a.s., has the unbending point located $12.6 \mathrm{~m}$ from the meniscus. So, the defects can also be caused by the long distance between the position of the metallurgical length and the unbending point. These rules ${ }^{8}$ together with the method for the optimum cooling ${ }^{9}$ give a set of conditions for the optimization of the casting parameters.

\section{RESULTS AND DISCUSSION}

According to the optimization criteria, the numerical model and fuzzy-regulation algorithm ${ }^{6}$ were used to calculate new casting parameters for the exanimated steel. In order to get the metallurgical-length position between $12-15 \mathrm{~m}$, the casting speed has to decrease to $89 \%$ of the original speed. The cooling intensity for the particular cooling circuit increases, on average, to
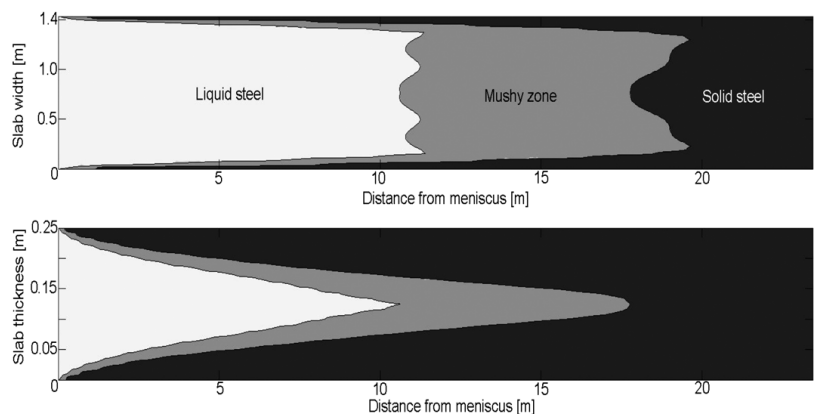

Figure 8: Distribution of liquid and solid steel Slika 8: Porazdelitev tekočega in trdnega jekla 


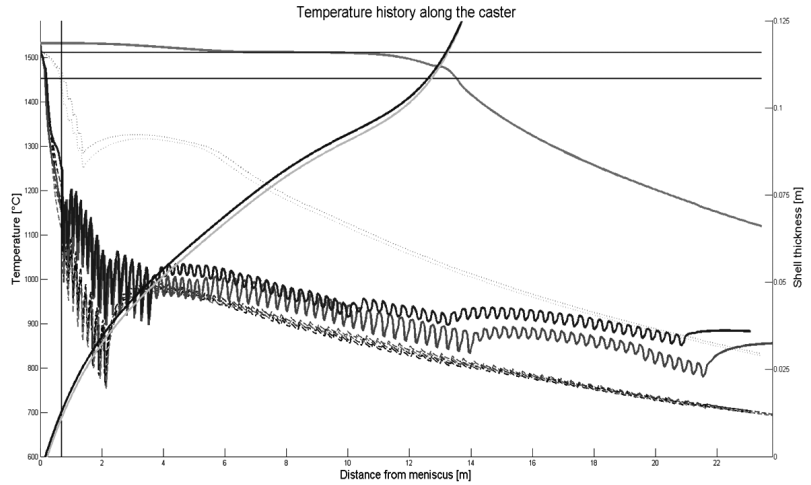

Figure 9: Temperature distribution after optimization Slika 9: Porazdelitev temperature po optimizaciji
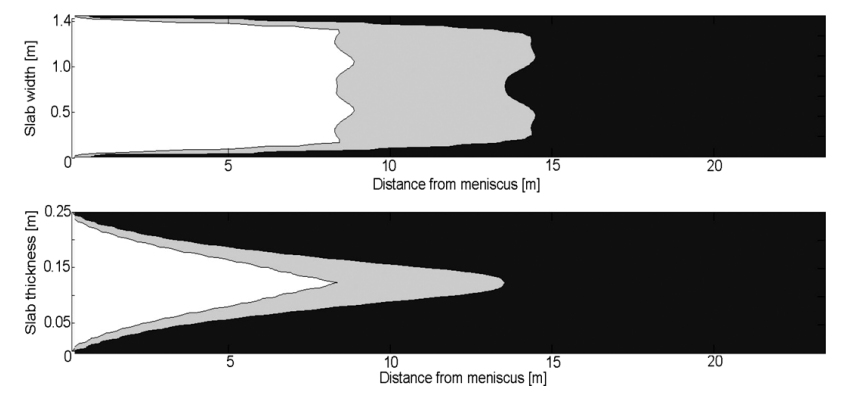

Figure 10: Distribution of liquid and solid steel

Slika 10: Porazdelitev tekočega in trdnega jekla

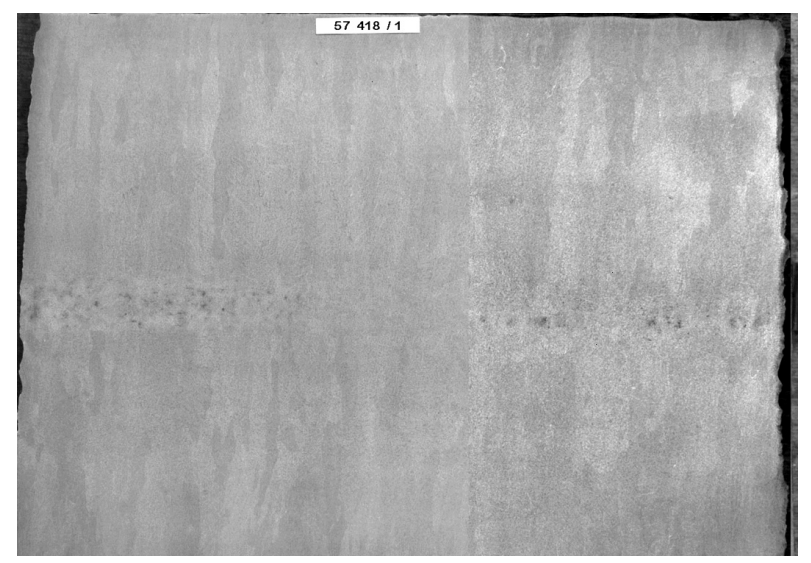

Figure 11: Steel sample from the casting after optimization Slika 11: Vzorec litega jekla po optimizaciji

$13.4 \%$. The results of the numerical simulation and optimization are in Figures $\mathbf{9}$ and $\mathbf{1 0}$.

The result was given to the Vitkovice Steel, a.s., as a casting recommendation for this type of steels. Despite the fact that the first macroscopic results (Figure 11) show a quality improvement, more experimental measurements and numerical simulations are required in order to get a general view of the behavior of the examined steel.

\section{CONCLUSION}

Numerical modeling and optimization will play an increasing role in the future improvements to the continuous casting of steel. A combination of the optimization algorithm based on fuzzy logic with the numerical model of the temperature field improves the casting parameters. With the optimum casting parameters, a better final quality of cast steel can be achieved. The algorithm is very general and its calculations can be used for any steel grade and caster geometry.

\section{Acknowledgement}

This work is an output of the research and scientific activities of NETME Centre, the regional R\&D center built with the financial support from the Operational Programme Research and Development for Innovations within the project NETME Centre (New Technologies for Mechanical Engineering), Reg. No. CZ.1.05/2.1.00/ 01.0002 and, in the follow-up sustainability stage, supported through NETME CENTRE PLUS (LO1202) with the financial means from the Ministry of Education, Youth and Sports under the "National Sustainability Programme I".

\section{REFERENCES}

${ }^{1}$ J. P. Birat et al., The Making, Shaping and Treating of Steel: Casting Volume, 11th edition, AISE Steel Foundation, Pittsburgh, PA 2003, 1000

${ }^{2}$ Crude steel production, The World Steel Association [online], Brussels, Belgium 2013 [cit. 2013-03-27], http://www.worldsteel.org/

${ }^{3}$ C. A. Däcker et al., The History of Mould Slag Films Downwards the Mould and How it Affects Heat Flux and Shell Growth in Continuous Casting of Steels, Proceedings of the METEC InSteelCon 2011, Düsseldorf 2011, 8

${ }^{4}$ A. Flick, Ch. Stoiber, Trends in Continuous Casting of Steel - Yesterday, Today and Tomorrow, Proceedings of the METEC InSteelCon 2011, Düsseldorf 2011, 8

${ }^{5}$ Y. H. Chang et al., Development and Application of Dynamic Secondary Cooling and Dynamic Soft Reduction Control for Slab Castings, Proceedings of the METEC InSteelCon 2011, Düsseldorf 2011, 6

${ }^{6}$ T. Mauder, C. Sandera, J. Stetina, A Fuzzy-Based Optimal Control Algorithm for a Continuous Casting Process, Mater. Tehnol., 46 (2012) 4, 325-328

${ }^{7}$ T. Mauder, C. Sandera, J. Stetina, Optimal control algorithm for continuous casting process by using fuzzy logic, Steel Res. Int., 86 (2015) 7, 785-798, doi:10.1002/srin.201400213

${ }^{8}$ G. S. Jansto, Steelmaking and Continuous Casting Process Metallurgy Factors Influencing Hot Ductility Behavior of Niobium Bearing Steels, Proceedings of the METAL 2013, Brno, 2013, 32-39

${ }^{9}$ A. A. Ivanova, V. A. Kapitanov, A. V. Kuklev, Method of calculating the optimum parameters for the air-mist cooling of a continuous-cast slab, Metallurgist, 56 (2012), 173-179, doi:10.1007/s11015-0129555-2 